\title{
THE PROBLEMS OF HISTOLOGICAL DIAGNOSIS IN BASO-SQUAMOUS CELL CARCINOMA OF THE SKIN
}

\author{
BY \\ J. BURSTON* AND R. D. CLAY \\ From the Portsmouth and I.O.W. Area Pathological Service
}

(RECEIVED FOR PUBLICATION JULY 3, 1958)

Following Jacob's clinical description in 1827 and Krompecher's histological investigations in 1900 and 1903, basal-cell carcinoma was regarded as a single clinical and pathological entity.

In 1910, however, MacCormac reported a series of rodent ulcers and suggested that on histological grounds there were three types of tumour, viz., pure rodent ulcers, mixed rodent ulcers (basalcell and squamous-cell tumours side by side), and intermediate types in which "great difficulty was experienced in determining whether the neoplasm should be classified as a rodent ulcer or as a Malpighian cancer." Korbl (1912) subsequently described a transitional form of skin cancer having the structure of a typical basal-cell carcinoma, but in which the cells were larger, paler, and richer in cytoplasm, approaching the prickle cell type. In these tumours some of the cells were arranged concentrically and intercellular bridges were present.

Darier (1922), in discussing the problems of skin cancer, also drew attention to variations in the histological pattern of some basal-cell carcinomata and suggested that this group of atypical basal-cell tumours should be called "épithéliome métatypique," of which he recognized two types, "épithéliome métatypique mixte" and "épithéliome métatypique intermédiare." The former he described as having the configuration of a typical basal-cell carcinoma with areas of conglomerate squamous cells, pale, and acidophilic, often with prickles but without keratohyalin and surrounding a colloid centre. The intermediate type was described as having narrow trabeculae, two or three cells thick, the cells being larger and paler than basal cells, though not as large as prickle cells, and prickles were frequently absent.

Montgomery (1928), in a study of 119 cases of epithelioma of the skin, found 15 cases which he regarded as transitional between basal and squamous-cell carcinoma, and to these he applied

*Present address: Department of Pathology, St. Thomas's Hospital, London, S.E.1. the name "basal squamous cell epithelioma." He defined this term solely by citing case histories, though before detailing these he stated: ". . . but pearl formation, even though incomplete, or the appearance of prickle cells in places is not the picture belonging to a true basal cell epithelioma." In the case histories pearl formation-usually incomplete-with colloid-like material at the centre of these pearls, together with areas of large pale cells and occasional prickles, are the criteria on which the diagnosis of baso-squamous carcinoma was made.

Each of these authors stresses the importance of making the specific histological diagnosis of this type of tumour since radio-resistance and recurrence were thought to be common and metastasis likely, though none of them personally quotes cases in which metastasis had occurred.

These views seem to have been widely accepted at the time and little attention has been directed to this problem since the early descriptions. Lennox and Wells (1951) have recently made a study of differentiation in basal-cell carcinomata and concluded that it was doubtful if basosquamous cell carcinoma was an entity. In the same journal, however, Thackray (1951) accepts baso-squamous cell carcinoma as an entity, though he does not define it.

This conflict of opinion is also expressed in the works of reference on which the average clinical pathologist has to rely when faced with a doubtful section. Thus Ackerman (1953) says that " practically all lesions diagnosed as baso-squamous carcinoma are basal-cell carcinoma and behave as such." Essentially similar are the views of Lever (1949, 1954), Evans (1956), and Allen (1953, 1957), who state that the appearances usually interpreted as baso-squamous cell carcinoma are simply areas of keratinization in basal-cell carcinomata and are of no prognostic significance. On the other hand, Barnard and Robb-Smith (1945) and MacLeod and Muende (1946) accept the existence of "metatypical carcinoma," and Willis (1953) refers to this 
type of tumour as "mixed basal and squamouscell carcinoma." Each of these authors regards relative radio-resistance as a feature of this tumour.

It was because of this sharp difference of opinion between the authors quoted above and also because we were uncertain of the possible prognostic significance of the diagnosis of basosquamous cell carcinoma that we undertook the present investigation. Interest was further stimulated by the knowledge that in the radiotherapy department here all cases diagnosed as baso-squamous cell carcinoma were treated as basal-cell carcinoma.

\section{Material for this Study}

Over the past seven years the diagnosis of basosquamous cell carcinoma was made on 28 skin biopsies. In each case the original section stained with haematoxylin and eosin was available for study and the diagnosis was reviewed and amended where necessary. The criteria applied to each case and the results are shown in Table I. In selecting points for study in each section those features mentioned in the original papers on baso-squamous cell carcinoma, together with those in the paper by Lennox and Wells (1951) on differentiation in basal cell carcinomas, were noted. Attention was also paid to stromal fibrosis, since it was pointed out by Umiker and Director (1954) that fibrosing basal cell growths were often misdiagnosed as baso-squamous cell carcinoma.

The follow-up on the cases has varied from six years to six months. Whilst it is appreciated that this period is too short so far as any worth-while assessment of recurrence is concerned, in each case we were in a position to judge the initial response to therapy, which is regarded as a significant point of difference between baso-squamous and pure basal-cell carcinomata.

Treatment was by a standard dose $(4,000 \mathrm{r})$ of superficial $x$ rays in 20 cases, the remaining eight cases being treated by biopsy excision.

\section{Results and Discussion}

At the outset of this study the immediate problem was that of defining baso-squamous cell carcinoma. A study of the literature unfortunately did not help. Indeed, it added to the confusion since, where illustrations have been given by authors, these seemed only to be examples of keratotic basal cell carcinomata (Montgomery, 1928 ; Willis, 1953). The only description which came near to being acceptable was that given by

TABLE I

CRITERIA FOR SELECTION AND RESULTS IN PRESENT SERIES

\begin{tabular}{|c|c|c|c|c|c|c|c|c|c|c|c|c|c|}
\hline $\begin{array}{c}\text { Case } \\
\text { No. }\end{array}$ & $\begin{array}{l}\text { Pali- } \\
\text { sading }\end{array}$ & Whorls & Colloid & $\begin{array}{l}\text { Kerato- } \\
\text { hyalin }\end{array}$ & $\begin{array}{l}\text { Keratin- } \\
\text { ization }\end{array}$ & Prickles & $\begin{array}{l}\text { Large } \\
\text { Cells }\end{array}$ & $\begin{array}{l}\text { Trab- } \\
\text { eculae }\end{array}$ & $\begin{array}{l}\text { Fib- } \\
\text { rosis }\end{array}$ & $\begin{array}{l}\text { Pig- } \\
\text { ment }\end{array}$ & $\begin{array}{l}\text { Secre- } \\
\text { tion }\end{array}$ & $\begin{array}{c}\text { Spindle } \\
\text { Cells }\end{array}$ & Revised Diagnosis \\
\hline 1 & - & + & - & - & - & - & + & $\ldots$ & - & - & + & + & Basal cell carcinoma \\
\hline 2 & - & + & -- & + & + & + & + & - & - & - & - & - & Seborrhoeic wart \\
\hline 3 & + & - & $\cdots$ & - & - & - & + & + & + & - & + & + & Fibrosing basal cell carcinoma \\
\hline 4 & - & + & - & + & + & + & + & - & - & -- & - & - & Squamous cell carcinoma \\
\hline 5 & - & + & - & - & + & + & + & - & - & - & - & - & Keratotic basal cell carcinoma \\
\hline 6 & + & + & + & + & + & - & + & + & + & - & - & + & Basal cell carcinoma \\
\hline 7 & + & + & - & + & + & - & + & - & -- & - & - & - & Seborrhoeic wart \\
\hline 8 & + & - & - & + & + & + & + & - & - & - & - & - & $\begin{array}{l}\text { Mixed squamous and basal } \\
\text { cell carcinoma }\end{array}$ \\
\hline 9 & + & + & -- & - & + & + & + & - & - & - & - & - & $\begin{array}{l}\text { Pseudo glandular squamous } \\
\text { cell carcinoma }\end{array}$ \\
\hline 10 & - & + & - & + & + & + & + & - & - & - & - & + & Hyperkeratosis \\
\hline 11 & - & - & -- & - & - & + & + & - & - & - & - & - & Warty naevus \\
\hline 12 & - & + & $\cdots$ & - & + & - & - & - & -.- & + & - & - & Keratotic basal cell carcinoma \\
\hline 13 & + & + & - & - & + & + & + & - & - & + & - & - & $\begin{array}{l}\text { Pseudo glandular squamous } \\
\text { cell carcinoma }\end{array}$ \\
\hline 14 & - & + & + & - & - & - & + & - & + & $\because$ & + & - & Keratotic basal cell carcinoma \\
\hline 15 & + & + & + & - & + & - & - & - & - & $-\dot{-}$ & + & 一 & ," ,, ," \\
\hline 16 & - & - & + & - & - & - & - & + & + & + & + & $-\overline{-}$ & Fibrosing ," ," \\
\hline 17 & - & - & + & - & $\overrightarrow{1}$ & - & + & + & + & - & + & + & Basal cell carcinoma \\
\hline 18 & + & + & - & + & \pm & - & + & - & - & - & $\vec{t}$ & $\overline{-}$ & \\
\hline $20 *$ & $\begin{array}{l}+ \\
+\end{array}$ & $\overline{-}$ & $\overline{-}$ & $\overline{-}$ & $\overline{-}$ & $\bar{t}$ & $\overline{+}$ & $\bar{t}$ & $\overline{+}$ & - & \pm & $\overline{-}$ & $\begin{array}{l}\text { Basal cell carcinoma } \\
\text { Fibrosing basal cell carcinoma }\end{array}$ \\
\hline $\begin{array}{l}20^{*} \\
21\end{array}$ & + & $\overline{+}$ & - & $\overrightarrow{+}$ & $\bar{t}$ & + & $\begin{array}{l}+ \\
+\end{array}$ & \pm & \pm & - & - & - & $\begin{array}{l}\text { Fibrosing basal cell carcinoma } \\
\text { Keratotic , , , }\end{array}$ \\
\hline 22 & - & + & + & - & + & -- & + & + & + & - & - & + & Fibrosing keratotic basal cell \\
\hline 23 & $\rightarrow$ & - & - & - & + & + & + & + & + & - & + & - & $\begin{array}{l}\text { Baso-squamous cell epidermal } \\
\text { tumour }\end{array}$ \\
\hline $24 \dagger$ & + & - & - & - & - & - & + & - & - & + & + & - & Basal cell carcinoma \\
\hline 25 & + & - & - & - & - & - & + & + & + & - & + & + & Baso-squamous cell carcinoma \\
\hline 26 & + & - & - & - & - & - & - & + & + & - & + & + & Fibrosing basal ,, \\
\hline 27 & - & + & - & + & + & - & $\overline{-}$ & + & + & - & + & + & Keratotic ,, ,, \\
\hline 28 & + & + & - & + & + & + & + & - & + & - & - & + & ," \\
\hline
\end{tabular}

* Case 20: Prickles and large cells in hyperplastic epidermis. † Case 24: Large cells at junction with epidermis only. 
MacCormac (1910), who stated: "This group includes a few growths where great difficulty is found in determining whether the neoplasm should be classified as a rodent ulcer or as a Malpighian cancer." Though this is an excellent assessment of the situation it remains too vague to be a definition.

For the purposes of this study baso-squamous cell carcinomata have been defined as that group of tumours which has the overall pattern of basal cell carcinoma and cytologically shows areas of basal cells differentiating into neoplastic squamous cells. In framing this definition we have been influenced by a number of considerations. Clearly, unless a tumour has some of the features of a basal cell carcinoma, consideration of a diagnosis of baso-squamous carcinoma is not likely to arise. Where squamous cell differentiation has occurred in a basal cell carcinoma, unless the squamous cells themselves show malignant features, they are unlikely to influence the prognosis of the tumour, and thus any diagnosis which draws attention to them would be therapeutically valueless. This view has been previously stated by Broders (1925), who pointed out that cells showing signs of keratinization are not capable of reproduction and that such cells are not active cancer cells. They cannot therefore of themselves be regarded as evidence of increased malignancy in any tumour in which they occur.

As defined here, a baso-squamous cell carcinoma is the malignant counterpart of the basosquamous cell tumour (baso-squamous cell acanthoma) discussed and illustrated by Lund (1957). He describes this latter tumour as a benign epidermal tumour consisting of a haphazard mixture of small basal cells and larger squamous cells in irregular zones or rounded foci, inflammation of the connective tissue being variable though an almost constant feature. Khanolkar (1947) described such a tumour which he regarded as an epithelioma. In this series of cases there was one example of the baso-squamous cell tumour (Fig. 1).

Having formulated a definition, it is apparent that basal-cell carcinomata in which there are areas of keratinization, large pale acidophilic cells with or without prickles, and colloid degeneration of the centre of cell masses, are not to be classified as baso-squamous cell carcinomata, though it is realized that Montgomery (1928) would have done so. Likewise, Darier (1922) would have regarded these tumours as "épithéliome métatypique," and this view would be supported by Barnard and

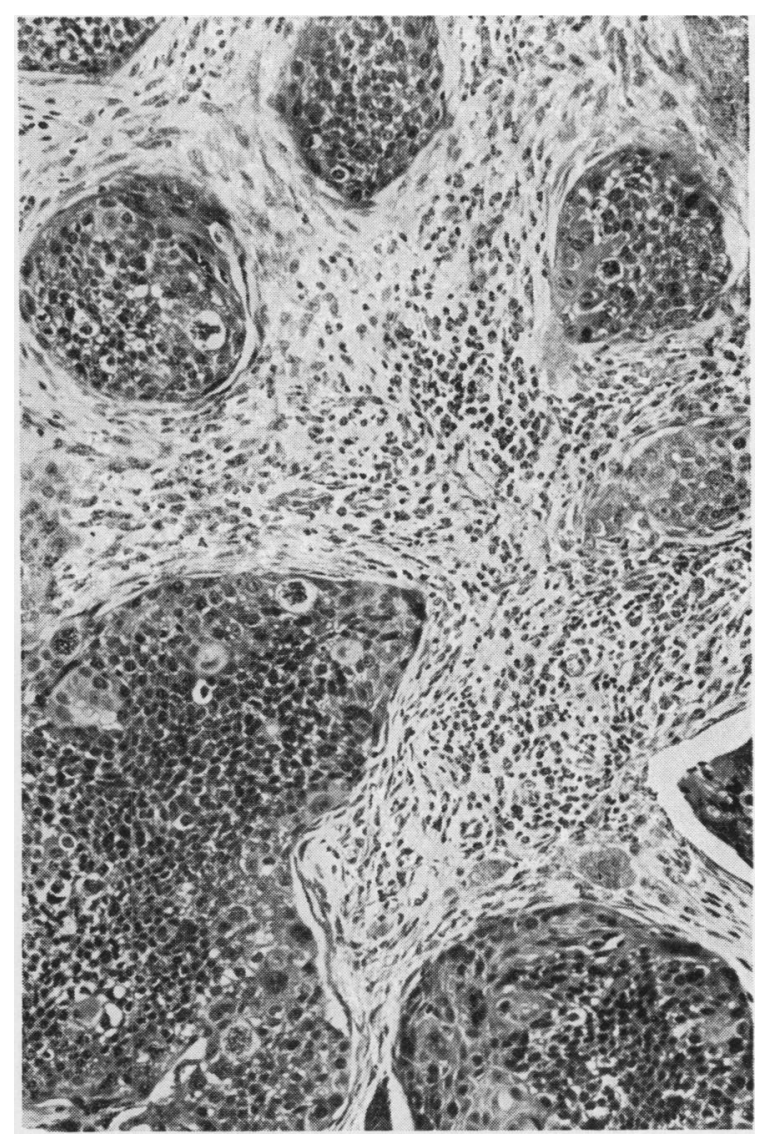

FIG. 1.-Baso-squamous cell tumour showing haphazard arrangement of basal and squamous cells with inflammation of stroma. (Haematoxylin and eosin, $\times 140$.

Robb-Smith (1945), MacLeod and Muende (1946), and Willis (1953).

Tumours in which there are separate foci of squamous and basal cell carcinoma should be described as such and should not give rise to difficulty in diagnosis or treatment (contiguous basal and squamous cell carcinoma).

The results of analysis of this series of tumours are given in Table II. The most

TABLE II

ANALYSIS OF TUMOURS

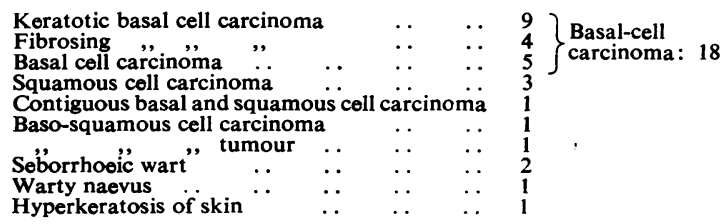


strange conclusion reached was that only one case out of the total of 28 could be regarded as a baso-squamous carcinoma as here defined. Even the case that has been accepted has much more the appearance of a mixed basal and squamous cell carcinoma (Fig. 2). However, as the two tumours are intimately mixed, in a few areas carcinomatous basal cells and squamous cells being continuous as distinct from contiguous, this case is acceptable as baso-squamous cell carcinoma (Fig. 3). A single case is not suitable for assessment of any therapeutic regimen. This case was treated by excision biopsy 15 months ago and there is no evidence of recurrence or metastasis to date.

With only one case of baso-squamous cell carcinoma to consider the natural history of this type of tumour cannot profitably be discussed. We would say, however, that in our experience it is a very rare tumour, constituting $0.018 \%$ of the 560 basal cell carcinomata seen in this department during the years covered by this study.

Though this study has not greatly advanced knowledge of baso-squamous cell carcinoma, a consideration of a number of the histological appearances present in this series of cases, with a possible explanation of the diagnostic errors which have been made, seems to be warranted. The four cases with benign epithelial hyperplasia are excluded from further consideration, though the fact that a diagnosis of baso-squamous cell carcinoma was applied to benign conditions signifies, amongst other things, some confusion as to what constitutes this tumour.

From Table II it can be seen that out of the original 28 cases 18 are reclassified as basal-cell carcinomas. In each of these cases a simple report of "basal-cell carcinoma of skin" or "rodent ulcer" should have been issued, and subdivisions have been made here purely for the purposes of discussion. That simple reporting, as indicated, is adequate is supported by the subsequent clinical course of the cases. Of the series, 10 cases were treated by radiotherapy and eight by excision. Only one case of undifferentiated basalcell carcinoma showed delayed response to $x$ ray, and even this lesion was completely healed within 10 weeks, and it had not recurred 10 months after treatment. Case 12 was treated by excision and recurred, but the section from the first excision indicates that it was incomplete and thus it is doubtful if this was a true recurrence. On each occasion the tumour was a basal cell carcinoma with areas of keratinization in it. The tumour in Case 27 recurred nine months after radiotherapy.
The original tumour, which is included in this survey, was a basal cell carcinoma in which there were areas of keratinization; the recurrence was entirely undifferentiated. The number of cases in this series and the recurrence rate are too small to justify the drawing of firm conclusions. However, the recurrence of one case out of 10 after radiotherapy is comparable with a recurrence of $12.9 \%$ at three years in a series of cases treated by surface application of radium reported by Magnusson (1935). As already indicated, it is doubtful if the one recurrence after surgical excision represents true recurrence. Any figures relating to recurrence after excision are inevitably of doubtful significance since, whereas adequate excision is curative of the tumour in question, separate foci of development are often a feature of basal-cell growths.

Of the 18 cases now regarded as basal-cell carcinoma, nine showed areas of keratinization within the tumour cell masses (Fig. 4). This type of tumour is commonly referred to as keratotic basal-cell carcinoma, and it is this failure to appreciate the fact that keratotic foci are a feature of basal-cell carcinomas without prognostic importance which has led to the diagnostic errors in these cases and to the original descriptions of baso-squamous cell carcinoma. The significance of these keratotic foci remains in doubt. They do not appear to be cell nests comparable to those of squamous-cell carcinoma (Darier, 1922 ; Montgomery, 1928) or abortive hair follicles (Haythorn, 1931) or sweat duct orifices (Foot, 1947). For reasons already given it is impossible to envisage their having any adverse prognostic significance, and such has proved to be the case in this series. It is of interest to recall that this type of tumour is regarded as being radio-resistant, though radioresistance was not encountered in this series. Dr. I. W. Whimster has kindly lent a section of such a tumour which has been irradiated with the resultant destruction of tumour cells, leaving minute horn cysts, i.e., micro-epidermoid cysts (Fig. 5). In such a situation there would be fine nodularity of the skin in the treated area, suggesting radio-resistance.

True prickles were detected in three out of the nine cases of keratotic basal cell carcinoma, and their presence no doubt confirmed the original observers' views that here was further evidence of squamous-cell carcinoma, though Dubreuilh and Auché reported the existence of prickles in basal cell tumours in 1901. Pseudo prickles, which appear to be the result of secretory activity of the 


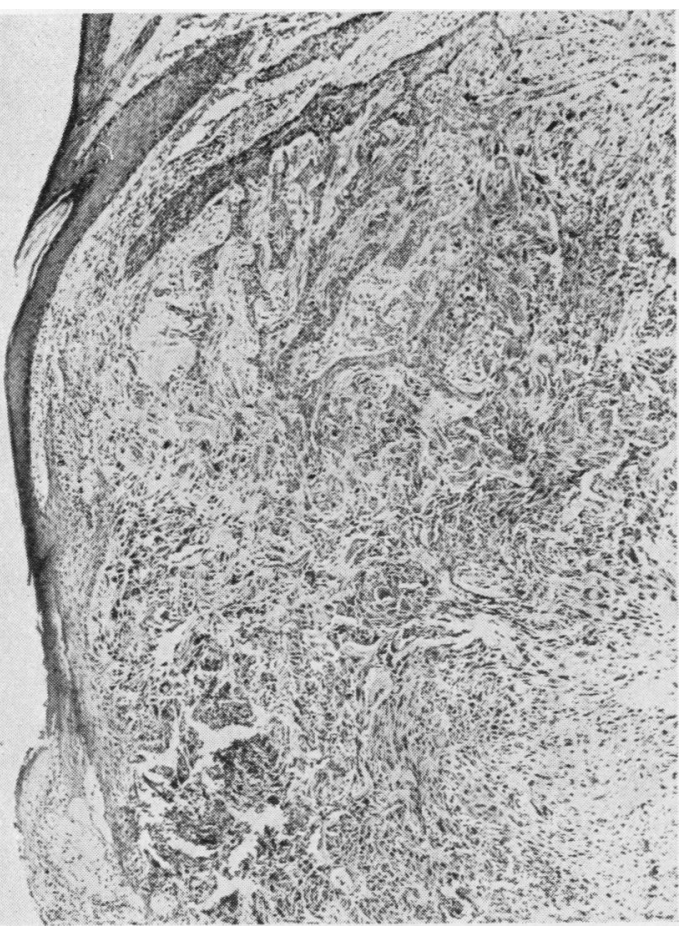

FIG. 2.-Baso-squamous cell carcinoma. At the edge of the lesion the appearance is that of a trabecular basal cell carcinoma. This tissue blends with spindle cell squamous carcinoma in which individual cell keratinization is occurring. (Haematoxylin and eosin, $\times$ 40.)

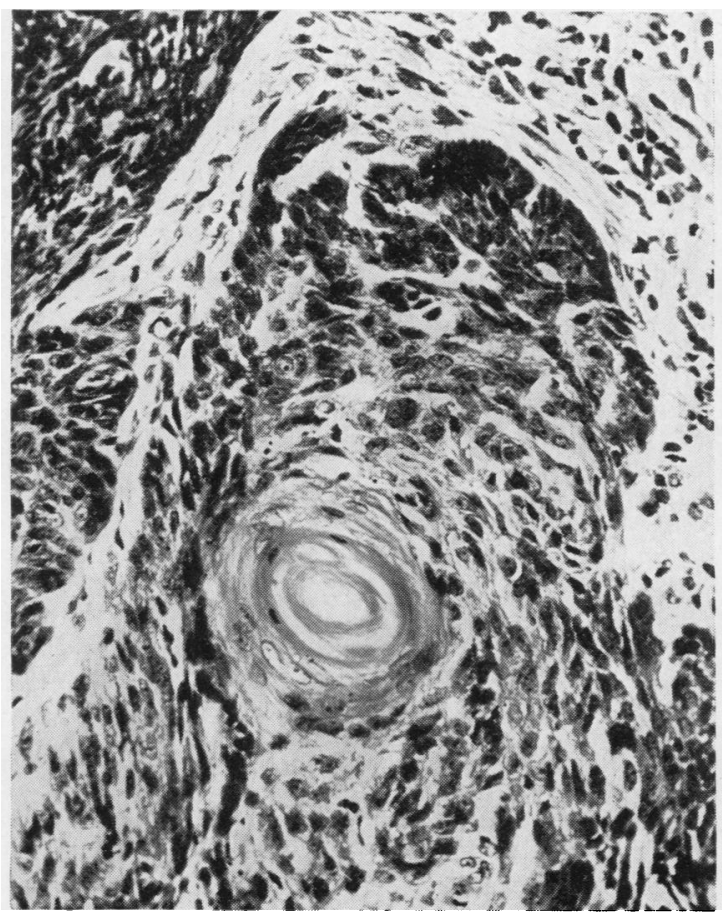

FIG. 4.-Keratotic basal cell carcinoma. An area of keratinization is present to one side of the centre of a clump of basal cells. This change was not present in adjacent areas. (Haematoxylin and eosin, $\times$ 270.)

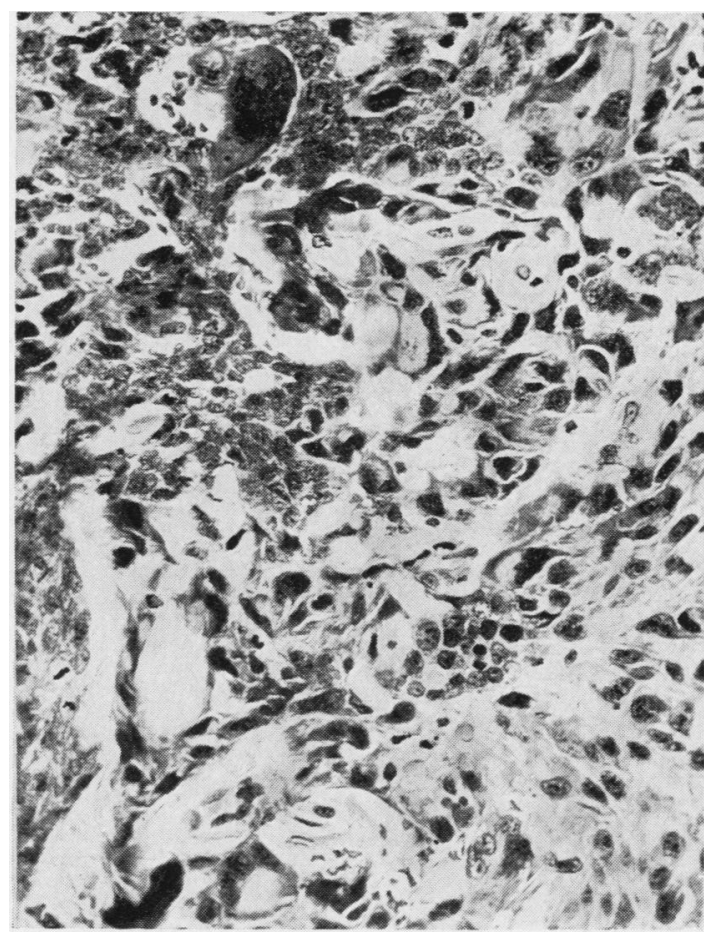

Fig. 3.-Baso-squamous cell carcinoma. High-power view of Fig. 2. (Haematoxylin and eosin, $\times 270$.)

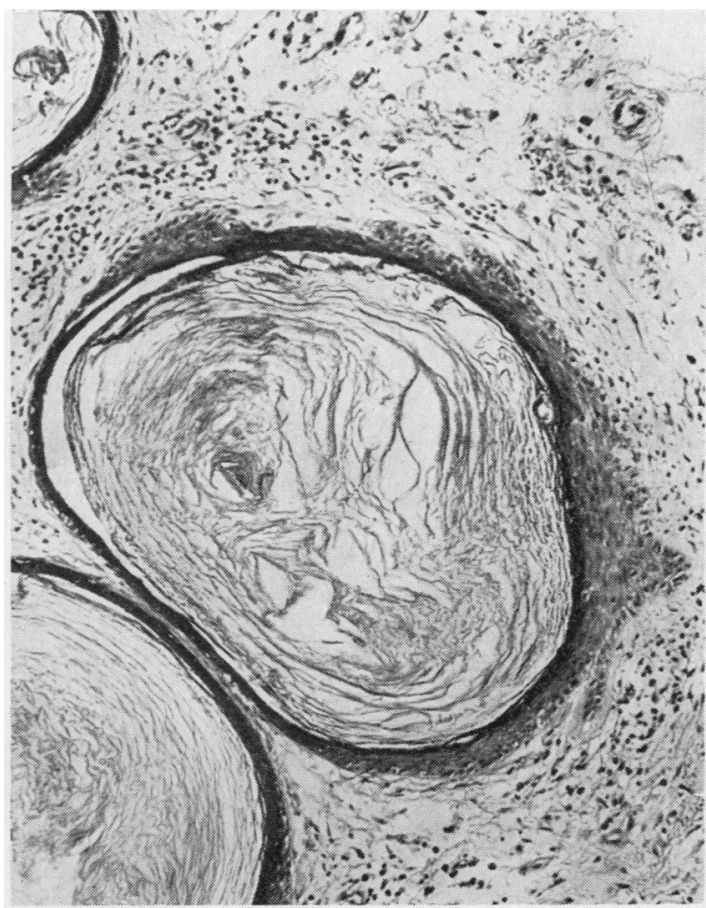

FIG. 5.-Irradiated keratotic basal cell carcinoma. The tumour tissue has been destroyed leaving a small hair cyst surrounded by normal squamous cells. (Courtesy of Dr. I. W. Whimster.) (Haematoxylin and oosin, $x$ 120.) 


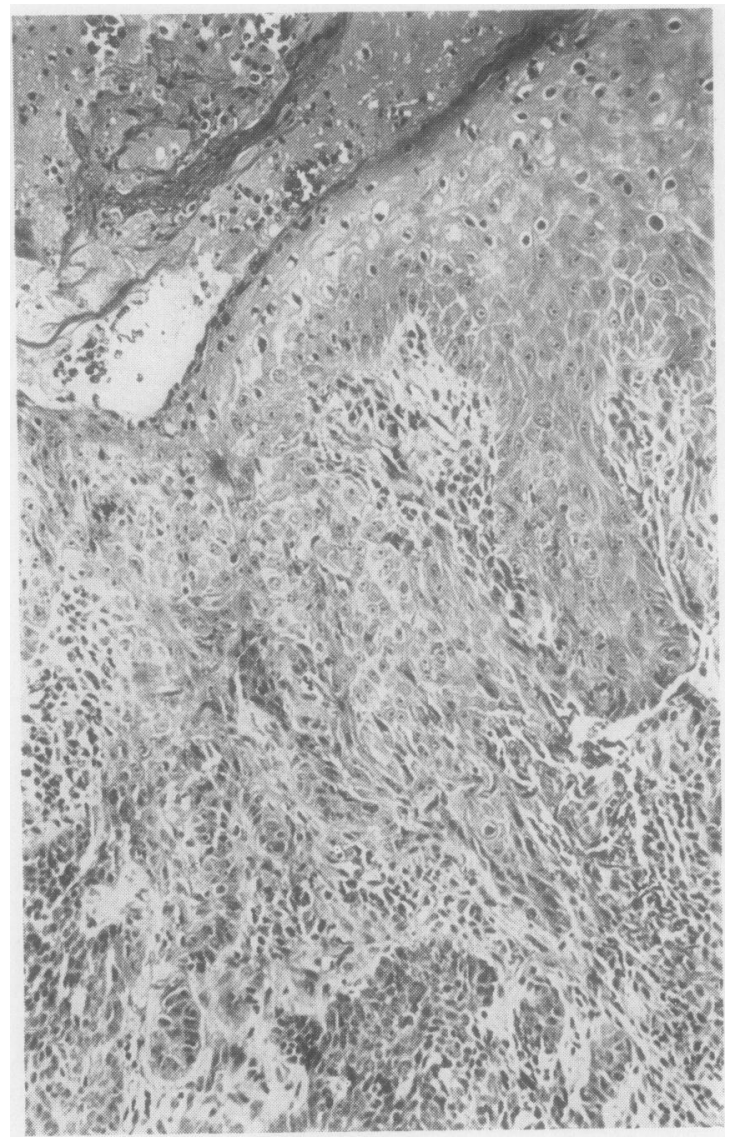

FIG. 6.-Pseudo epitheliomatous hyperplasia at the edge of an ulcerated basal cell carcinoma. (Haematoxylin and eosin, $\times 140$.)

tumour cells (Lennox and Wells, 1951), are often seen and they constitute a trap for the unwary.

Four cases in the basal cell group showed a marked connective tissue response to the invasion of the tumour. The resultant microscopic picture is of a trabecular infiltrative type of tumour in which it is difficult to delineate the typical basal cells from the larger eosinophilic fibrocytes, these latter being liable to interpretation as squamous cells. Attention was drawn to this diagnostic difficulty by Umiker and Director (1954), who showed that this appearance had no prognostiz significance. Once aware of the appearances of these fibrosing basal cell growths, no difficulty is encountered in interpreting them.

One final appearance, which was the cause of some difficulty and led to erroneous diagnoses, was hyperplasia of squamous epithelium at the edge of ulcerated lesions. Such epithelial hyperplasia is of course not uncommon at the edge of chronic skin ulcers, and it is mentioned specifically at the edge of rodent ulcers by Thackray (1951) and by Lund (1957), the former author regarding it as squamous metaplasia of tumour cells. On general grounds, however, it is more likely to represent reactive hyperplasia of the squamous epithelium at the edge of the ulcer. Cases 17, 20, and 24 showed this appearance, and in each this was the only evidence of any squamous element in the tumour (Fig. 6).

Brief reference should be made to the three cases of squamous-cell carcinoma which gave rise to diagnostic difficulty and error. Two of the three cases were of pseudo glandular typeclumps of epithelium with low cuboidal cells with hyperchromatic nuclei at the periphery and larger eosinophilic cells at the centre, many of these latter cells appearing to have been desquamated-which perhaps bears a remote resemblance to a keratotic basal-cell carcinoma. The third case of squamous-cell carcinoma was an intra-epidermal tumour showing early invasion, and it is not easy to see what the diagnostic difficulty was in relation to the problem.

\section{Summary and Conclusions}

A histological diagnosis of baso-squamous cell carcinoma of the skin had been made on 28 biopsies in this department in the seven years 1951-7. Each section was reviewed.

The unsatisfactory descriptions and definitions in the literature are discussed and a definition proposed.

Using this definition, only one case could be regarded as a baso-squamous cell carcinoma. As the total number of basal-cell carcinomata seen in this department during the years covered by the survey was 560 , this makes an incidence of only $0.018 \%$.

The possible causes of erroneous diagnosis are discussed with a consideration of certain appearances in basal and squamous cell carcinomata.

We wish to thank Mr. R. W. Gunderson, Dr. J. B. McEwen and Dr. A. Aitken Ross for access to clinical records, and Dr. I. W. Whimster for Fig. 5 and much useful discussion. The photomicrographs were taken by Mr. A. E. Clark to whom thanks are also due.

\section{REFERENCES}

Ackerman, L. V. (1953). Surgical Pathology, p. 86. Kimpton, London.

Allen, A. C. (1953). In Pathology, 2nd ed., p. 1161. Ed. W. A. D. Anderson. Mosby, St . Louis.

(1957). Ibid., 3rd ed., p. 1162. Mosby, St. Louis. 
Barnard, W. G., and Robb-Smith, A. H. T. (1945). Kettle's Pathology of Tumours, 3rd ed., p. 212. H. K. Lewis, London.

Broders, A. C. (1925). Med. J. Rec., 121, 133.

Darier, J. (1922). Brit. J. Derm., 34, 145.

Dubreuilh, W., and Auchś, B. (1901). Ann. Derm. Syph. (Paris), 2, 705. Quoted by MacCormac, 1910.

Evans, R. Winston (1956). Histological Appearances of Tumours, p. 303. Livingstone, Edinburgh and London.

Foot, N. C. (1947). Amer. J. Path., 23, 1.

Haythorn, S. R. (1931). Amer. J. Cancer, 15, 1969.

Jacob, A. (1827). Dublin Hosp. Rep., 4, 232.

Khanolkar, V. R. (1947). Cancer Res., 7, 692.

Korbl, H. (1912). Arch. klin. Chir., 97, 752.

Krompecher, E. (1900). Beitr. path. Anat., 28, 1.

— (1903). Der Basa!zellenkrebs. Fischer, Jena.

Lennox, B., and Wells, A. L. (1951). Brit. J. Cancer, 5, 195.
Lever, W. F. (1949). Histopathology of the Skin, 1st ed., p. 329. J. B. Lippincott, Philadelphia.

- (1954). Ibid., 2nd ed., p. 379.

Lund, H.Z. (1957). Tumors of the Skin. (Atlas of Tumor Pathology. Sect : 1-Fasc. 2.) Armed Forces Institute of Pathology, Washington, D.C.

MacCormac, H. (1910). Arch. Middlesex Hosp., 19: Ninth Report. From the Cancer Research Laboratories, p. 172. (1924), Brit. med. J., 2, 457.

MacLeod, J. M. H., and Muende, I. (1946). Practical Handbook of the Pathology of the Skin, 3rd ed., p. 102. H. K. Lewis, London.

Magnusson, A. H. W. (1935). Acta radiol. (Stockh.), Suppl. 22.

Montgomery, H. (1928). Arch. Derm. Syph. (Chicago), 18, 50.

Thackray, A. C. (1951). Brit. J. Cancer, 5, 213.

Umiker, W., and Director, W. (1954). A.M.A. Arch. Derm. Syph., $69,486$.

Willis, R. A. (1953). Pathology of Tumours, 2nd ed., p. 278. Butterworth, London. 